Volume 27, 2017

http://journals.sfu.ca/cjsdw

\title{
Article
}

\section{Writing on the Ground}

\section{Janna Klostermann}

Carleton University

This essay responds to the recent "Statement on Writing Centres and Staffing" (Graves, 2016), making visible differing conceptualizations of writing in it. More particularly, I will make visible traces of the statement that position writing as a measurable skill, aligning with the priorities of university administrators, and traces of the statement that position writing as a complex social practice, aligning with the needs of student writers and writing centre tutors/specialists. I trouble understandings of writing that maintain the university as a site of exclusion, while pushing for future contributions that take seriously the everyday, on the ground work of student writers and writing centre tutors/specialists.

The call for responses for this special section, "The Future of Writing Centres in Canada," led off with news of Canadian university writing centres' shutdowns, relocations, and job losses:

In the past three years, writing centres at Canadian universities have been established, revisioned, and shut down. At some universities, services traditionally housed in writing centres have been relocated; at others, writing specialists have lost their jobs. Change seems to be in the air. (Heng Hartse, Chen, \& Graves, 2016)

I read the "Statement on Writing Centres and Staffing" (Graves, 2016) against this backdrop. It is no wonder that much of the statement is devoted to asserting that writing centres are, indeed, critical agents within universities. The statement's priorities align well with university priorities. For example, the statement underscores that writing centres play a vital role in promoting academic excellence, in helping students adapt and succeed in their programs, and in addressing degree outcomes. The statement, again, positions writing centres as critical agents in universities, making the work of writing centres and staff legible to university administrators.

I recognize the importance of connecting writing centres' work to institutional strategic plans. Writing centres need university funding and support to provide services and to employ 
Volume 27, 2017

http://journals.sfu.ca/cjsdw

qualified writing centre tutors/specialists. The statement does important work to hook up the work of writing centres to university agendas. That said, as a novice writing studies researcher and practitioner, I read the statement as aligning more with the aims of university administrators than with the needs of student writers or writing centre tutors/specialists. Motivated by these observations, this essay revisits the statement, making visible differing conceptualizations of writing in it. Just as people use writing to reinforce and recontextualize links between themselves and others (Tusting, 2015), I argue that the statement reinforces links between writing centre administrators and university administrators, while at times turning away from the work of student writers and writing centre tutors/specialists. To close, I highlight the need for future contributions that centre the everyday, on the ground work of student writers and writing centre tutors/specialists.

With my training in writing studies and institutional ethnography, I consider writing as a complex social and institutional practice, and align my work with Bryant's (2017, this issue) writing as social action narrative. Writing isn't about particular, lone skills that can be taught or learnt once and for all (Russell, 2002), nor is it about holing oneself away out of reach from others. Writing is a way to get things done (Paré, 2009), to meet social goals (Artemeva \& Freedman, 2006), and to stitch oneself into particular social or institutional relations (Smith, 2005). Writing can be a powerful way to participate in dialectic and democratic processes within and beyond academe (Brodkey, 1995). Written texts do not stand alone; they are connected to other practices and relations and to near and far-flung others (Smith, 2005). Similarly, writing instruction isn't simply about supporting others in producing a final product or final display of knowledge, but about supporting others in constructing new knowledges, engaging in ongoing identity work, and navigating particular conventions, conversations and communities (Hyland, 2004; Paré, Starke-Meyering, \& McAlpine, 2011). Writing and writing instruction are social and institutional practices - not particular skills or strategies that can be mastered once and for all.

Yet, reading the statement, I noticed contributions that conceptualize writing as a product or skill, reflecting what Bryant (2017, this issue) calls the writing as skill narrative. The statement does this in a few key ways. First, the statement, again, underscores the role of writing centres in promoting academic excellence, in helping students adapt and succeed in their programs, and in addressing degree outcomes. Second, by emphasizing quality and a direct correlation between mentoring and performance, the statement frames writing instruction as a specialized skill that can be taught and measured rather than as an ongoing social process related to the tutor/specialist's ongoing learning and development. As the statement put it, "the quality of 
Volume 27, 2017

http://journals.sfu.ca/cjsdw

their [peer tutors] work depends almost entirely upon the quality of mentoring they receive" (p. 7). Third, the statement draws on research related to evidence-based support (Babcock \& Thonus, 2012) and program evaluation (Patton, 2015), while, at times, shying away from more progressive research related to writing as a complex social or institutional practice (Hyland, 2004; Paré, Starke-Meyering, \& McAlpine, 2011; Smith, 2005) as well as from research related to the radical, feminist or marginal work of writing centres (Alexander, 2004; Brodkey, 1996; Rohan, 2002; Schell, 1998). Finally, the statement undertheorizes the role of students as knowers and contributors, maintaining the university as a site of exclusion and positioning students on the outskirts of thinking and knowing: "as they [students] adapt to their programs and learn the ways of thinking as well as the knowledge in the field, they begin to write like members of the community (Paré, 2002)" (p. 6, emphasis added). Rather than positioning students as members of the community, this rendering, albeit subtly, excludes students from the university, and undervalues their thinking, knowing and writing practices. So, to summarize, the statement includes traces that conceptualize writing as a measurable, master-able product or skill and that maintain the university as a site of exclusion. These traces align more with the priorities of university administrators than with the slow, steady, and sometimes disappointing work of student writers and writing centre tutors/specialists.

That said, while the statement, at times, positions writing as a measurable skill, it also frames writing as a complex social practice, aligning with the work of student writers and writing centre tutors/specialists. The statement does this in a few ways. First, the statement includes traces that forward a social view of writing, stressing the importance of tutors/specialists having "knowledge of writing studies research and proven instructional models" (p. 5). Second, the statement underscores the role of apprenticeship in learning to write as well as the more-longterm nature of learning and development. As the statement puts it, "Writing is not simply a matter of learning to follow grammatically correct patterns of expression; rather, it is a tool to enable all the thinking and adapting that students must do in their studies" (Hillocks, 1985, 1986; Bean, 2011 as cited p. 6). Third, the statement attends to students with varying "language backgrounds and proficiency levels" (p. 6), acknowledging the needs of diverse student writers and reflecting the history of writing centres which emerged to help traditionally marginalized students navigate the academy (Waller, 2002). Finally, and perhaps most notably, the statement situates the work of student writers and the work of writing centre tutors/specialists outside of standalone writing centres and within the social and institutional relations of academe. The statement acknowledges that all students write in university and in the workplace, and that 
Volume 27, 2017

http://journals.sfu.ca/cjsdw

having writing centre tutors/specialists collaborate with faculty and academic units across disciplines can be generative. To summarize, the statement includes traces that underscore that students' ongoing learning and development occurs within and beyond writing centres and through and beyond particular interventions focused on skills or strategies. The statement, at times, conceptualizes writing as a complex social practice, reflecting the everyday work of diverse student writers and writing centre tutors/specialists.

Overall, I was encouraged by the statement collaborators' work to promote writing instruction and the discipline of writing studies in Canada. I hope that by revisiting their work, and making visible traces of differing conceptualizations of writing in it, this essay also contributes to these efforts. Taking it further, just as Smith (2008) pushes for change from below, warning against initiatives that are "divorced from the actualities of the everyday lives of those who participate" (p. 26), I push for future contributions that bring attention to, if not centre, the gritty, on the ground work of student writers and writing centre tutors/specialists.

\section{Acknowledgments}

Many thanks to Katie Bryant, Sibo Chen, Joel Heng Hartse and an anonymous reviewer for feedback on this essay.

\section{References}

Alexander, K. (2005). Liminal identities and institutional positioning: On becoming a "writing lady" in the academy. Inkshed, 22(3), 5-16.

Artemeva, N. \& Freedman, A. (Eds.). (2006). Rhetorical genre studies and beyond. Winnipeg, MB: Inkshed Publications.

Babcock, R. D., \& Thonus, T. (2012). Researching the writing center: Towards an evidencebased practice. New York, NY: Peter Lang.

Brodkey, L. (1995). Writing permitted in designated areas only. Minneapolis, MN: University of Minnesota Press.

Bryant, K. (2017). Interrogating conflicting narratives of writing: A call for research. Canadian Journal for Studies in Discourse and Writing/Rédactologie, 27, 13-18.

Graves, R. (2016). Statement on writing centres and staffing. Canadian Journal for Studies in Discourse and Writing/Rédactologie, 26, 5-10. 
Volume 27, 2017

http://journals.sfu.ca/cjsdw

Heng Hartse, J., Chen, S., \& Graves, R. (2016). Call for responses: Special sections on the future of writing centres in Canada in CJSDW/R. Retrieved from http://journals.sfu.ca/cjsdw

Hyland, K. (2004). Disciplinary discourses: Social interactions in academic writing. Ann Arbor, MI: University of Michigan Press.

Paré, A. (2009). What we know about writing, and why it matters. Compendium: writing, teaching, and learning in the university, 2(1), 1-7.

Paré, A., Starke-Meyerring, D., \& McAlpine, L. (2011). Knowledge and identity work in the supervision of doctoral student writing: Shaping rhetorical subjects. In D. Starke-Meyerring et al. (Eds.), Writing in knowledge societies (pp. 215-236). West Lafayette, IN: Parlor Press and WAC Clearinghouse.

Patton. M. Q. (2015, January 23). Impact evaluation: Best practices aren't [Blog Post]. Retrieved from http://betterevaluation.org/

Rohan, L. (2002). Hostesses of literacy: Librarians, writing teachers, writing centers, and a historical quest for ethos. Composition Studies, 30(2), 61-77.

Russell, D. R. (2002). Writing in the academic disciplines: A curricular history. Carbondale, IL: SIU Press.

Schell, E. E. (1998). Gypsy academics and mother-teachers: Gender, contingent labor, and writing instruction. Portsmouth, NH: Boynton/Cook Publishers.

Smith, D. E. (2005). Institutional ethnography: A sociology for people. Lanham, MD: AltaMira Press.

Smith, D. E. (2008). Making change from below. Socialist Studies: The Journal of the Society for Socialist Studies, 3(2), 7-30.

Tusting, K. (2015). I am a peacemaker: Writing as a space for recontextualizing children's identity in a catholic first communion preparation course. Written Communication, 32(3), 227-253.

Waller, S. (2002). A brief history of university writing centers: Variety and diversity. Retrieved from http://www.newfoundations.com/ 